Appeared in: Economic Policy 24, April 1997, pp. 179-210

\title{
FOREIGN DIRECT INVESTMENT, POLITICAL RESENTMENT AND THE PRIVATIZATION PROCESS IN EASTERN EUROPE
}

\author{
Hans-Werner Sinn and Alfons J. Weichenrieder*
}

\begin{abstract}
*An earlier version of this paper was part of a research project which the authors carried out for the European Bank for Reconstruction and Development (EBRD). The authors thank David Begg, Thomas Jelf, Hans-Peter Lankes, Ronnie Schöb, Richard Portes, István Székely for valuable discussion and useful information. We are particularly indebted to Alisa Roell and Bruno Frey who gave excellent comments to our paper. Additional information from UN/ECE and EBRD sources is gratefully acknowledged.
\end{abstract}




\title{
FOREIGN DIRECT INVESTMENT, POLICAL RESENTMENT
} AND THE PRIVATIZATION PROCESS IN EASTERN EUROPE

\begin{abstract}
Foreign direct investment has been disappointingly low in Eastern Europe, which has been reluctant to make existing assets available to foreign investors. To mitigate any such resentment, a participation model could be used in which foreign investors compete for joint venture contracts. Host governments contribute existing assets and receive non-voting stocks. Foreign investors, contributing capital and knowhow, receive voting shares and control of operational decisions. This has several advantages over the cash sale of assets to foreigners. First, stock flow problems are eased, raising both asset prices and FDI flows. Second, by retaining some stake in the firm, transition countries share in the risk premium. Third, governments can hand over their shares to households, creating private collateral to foster new small businesses. Fourth, and crucially, compared to cash sales the auction of participation contracts offers higher privatization revenues in cases where governments cannot assess investors' knowledge and abilities. This reduces the risk of selling the family silver too cheaply and should alleviate the host countries' resentment.
\end{abstract}

Hans-Werner Sinn

Center for Economic Studies

University of Munich and NBER

Schackstr. 4

80539 Munich

Germany

Tel.: ++498921802747

Fax ++4989397303

hans-werner.sinn@ces.vwl.uni-muenchen.de
Alfons J. Weichenrieder

Woodrow Wilson School

Princeton University

406 Robertson Hall

Princeton, NJ 08544-1013

USA

Tel.: ++1 6092584793

Fax ++1 6092582809

alfonsw@wws.princeton.edu 


\section{INTRODUCTION}

Six years after the iron curtain was lifted, the countries of the East have yet to recover from the transformation shock. Aggregate output remains below its 1990 level and aggregate employment in Central and Eastern Europe (CEE) is down by roughly 16\%. ${ }^{1}$ The more advanced economies - Poland, Hungary, the Czech Republic and Slovakia - have lost over $30 \%$ of their jobs since $1988 .{ }^{2}$ Communist governments have regained power in several countries.

The low level of foreign direct investment (FDI) has been a big disappointment. Eastern Europeans, lacking capital but with skilled labor and an abundance of natural resources, might have been expected to attract substantial FDI. In theory, given the continuing constraints on labor migration, mobile capital should have kept migrating to the East until its marginal product fell to western levels. With more capital, a higher demand for labor should have bid up eastern wages towards western levels.

Several forces undermined this simple arbitrage of international capital: difficulties installing the appropriate legal and institutional framework, without which market forces were unable to operate; insufficient funds for the public infrastructure that is a prerequisite for successful private investment; substantial economic and political risk involved in investing in the East.

Moreover, CEE countries were also unwilling to attract too much FDI. ${ }^{3}$ In transition economies, FDI has typically meant not greenfield investment but the purchase of existing assets, usually during privatization of state owned enterprises. Selling state assets to foreigners is often seen as 'selling the family silver' and encounters widespread political resistance.

\footnotetext{
1 Vienna Institute for International Comparisons (WIIW), WIIW Handbook of Statistics, Countries in Transition, 1995, and WIIW database. For this paper, CEE countries comprise Albania, Belarus, Bulgaria, Croatia, the Czech Republic, Estonia, Hungary, Latvia, Lithuania, Moldova, Poland, Romania, Russia, Slovakia, Slovenia, and the Ukraine.

2 OECD, Short-term Economic Statistics Central and Eastern Europe, 1992; OECD, Short-term Economic Indicators Transition Economies, 3/1996; OECD, Main Economic Indicators, July 1996.

${ }^{3}$ By direct as distinct from portfolio investment we mean investment that also carries a presumption of control. In practice, this is usually taken to mean either award of explicit control rights or ownership of at least $25 \%$ of the equity.
} 
We describe the development of FDI, document resentment to it, and argue this can be overcome by privatization strategies that raise higher revenues than cash sales do. We analyze FDI via a participation contract between the government and foreign investors subject to competitive bidding. The government contributes the asset to be privatized and the investor contributes the restructuring capital necessary to adapt the old capital to the new market environment. Each party retains shares equal to the value of its contribution; in a second step, the government then distributes its shares to the population, using vouchers or other forms of distribution. Similar participation contracts have been proposed by Sinn and Sinn (1991), Bolton and Roland (1992) and Demougin and Sinn (1994) for transition countries' internal privatization processes. One variant has actually been used in Bolivia, following suggestions summarized in Sinn and Sinn (1993). The present paper develops previous analyses, all within a context of FDI and resentment of it. We will argue that FDI via this participation contract is better than other forms of direct investment: it generates more privatization revenue and provides better investment incentives in the host country.

\section{WHERE IS THE FLOOD?}

Since the fall of the iron curtain, FDI to Central and Eastern Europe has been a trickle not a flood. By January 1996 the total accumulated inflow of FDI into CEE countries (excluding East Germany) was only US $\$ 43$ bn. ${ }^{4}$ In absolute terms, this is lower than FDI to just Argentina and Mexico in the same period, some US $\$ 47 \mathrm{bn}^{5}$; in per capita terms, this is just one third of the figure for Argentina and Mexico. Also, in per capita terms, if one includes FDI from West Germany, FDI to East Germany was over 100

\footnotetext{
4 Source: UN/ECE $(1994,1995)$.

5 IMF International Financial Statistics, Nov. 1996.
} 
times that to CEE countries (Table 1), a discrepancy that would have been even higher if East German wages had not risen tenfold after unification (see Sinn 1995).

Table 1. FDI to CEE and East Germany: cumulative to Jan 1996

\begin{tabular}{lrrr} 
Country & total & $\begin{array}{c}\text { per capita } \\
(\text { \$ US })\end{array}$ & $\begin{array}{c}\text { per capita } \text { as } \% \\
\text { that in East Germany }\end{array}$ \\
\hline Albania & 270 & 81 & 0.6 \\
Belarus & 331 & 32 & 0.2 \\
Bulgaria & 517 & 58 & 0.4 \\
Croatia & 1200 & 252 & 1.8 \\
Czech Republic & 5587 & 542 & 3.9 \\
Estonia & 646 & 409 & 2.9 \\
Hungary & 13740 & 1334 & 9.5 \\
Latvia & 485 & 181 & 1.3 \\
Lithuania & 352 & 94 & 0.7 \\
Moldova & 87 & 20 & 0.1 \\
Poland & 7843 & 204 & 1.5 \\
Romania & 1597 & 68 & 0.5 \\
Russia & 5875 & 39 & 0.3 \\
Slovak Republic & 726 & 138 & 1.0 \\
Slovenia & 2762 & 1399 & 10.0 \\
Ukraine & 891 & 17 & 0.1 \\
total & 42911 & 130 & 0.9
\end{tabular}

Sources: UN/ECE, East-West Investment News, database; Treuhandanstalt Final Report,1994; Institut der Deutschen Wirtschaft: Zahlen zur wirtschaftlichen Entwicklung der Bundesrepublik Deutschland, 1996; ifo-Schnelldienst 5/1995; Statistisches Bundesamt Wiesbaden, Mittel- und Osteuropa in Zahlen, July 1993; EBRD (1995).

Note: East Germany's FDI includes fixed investment by West German firms and Treuhand revenues received by selling firms; public investment not included. 1995 figure estimated by ifo-Institut.

Table 1 reports FDI into the CEE countries up to January 1996. Hungary, in absolute terms by far the largest recipient of FDI, had one third of the total. In per capita terms, Hungary ranks second, behind Slovenia but ahead of the Czech Republic and Estonia. Even so, Hungary's absolute inflow of FDI was only $\$ 13.7$ bn., compared with $\$ 219$ bn received by East Germany.

Of course, the East German situation was unique. West Germany pumped huge amounts of public funds into East Germany - about 1000 billion DM up to 1996 which then attracted private funds. Direct investors were not confronted with political hurdles. Indeed, privatization of state assets via cash sales to the most attractive bidders typically meant sales to West Germans. Measuring assets by the jobs entailed, 
only $6 \%$ of the East German assets went to East German investors, $85 \%$ to West Germans, 9\% to investors from other western regions. Surprisingly, East Germans showed little resentment of the fire sale of their assets. They were happy about the public funds they received from the West and did not worry about the redistribution of wealth that took place under the privatization programme.

CEE countries have no corresponding West Germany to whom they can easily sell $85 \%$ of available state assets. That is our point of departure: the importance for FDI of political constraints and the importance of finding ways to relax them.

\section{RESENTMENT AGAINST FOREIGN DIRECT INVESTMENT}

The poor FDI record of CEE countries reflects many things. Insecurity about property rights and regulatory constraints are crucial. The return to power of communist parties has irritated investors no less than the frequent policy of diluting existing shares by privileged issues of new shares to insiders. The partial replacement of public police by private Mafia has done nothing to calm their fears. In most countries, neither a workable civil code nor a functioning legal system for settling private disputes has been created. Western policies have contributed to the problems. EU restrictions on trade in 'sensitive sectors' (Rollo and Smith, 1993) has discouraged FDI in the CEE countries, since potential 'declining industries' in western Europe are precisely those in which CEE countries often enjoy a comparative advantage over the west.

While these aspects explain a low supply of FDI, they do not explain the surprisingly low demand for FDI. Appendix A illustrates, necessarily selectively, the mixed feelings in CEE countries about the role of FDI. They fear FDI makes a country vulnerable to foreign influence, a partial loss of sovereignty, and that national treasures are sold at fire sale prices to the West. Czech prime minister Vazlav Klaus asked foreign investors to wait until privatization is finished; his government has explicitly warned against selling the 'family silver'. In Hungary, opposition to privatization through foreigners has been growing. Polish privatization minister Gruszecki warned against giving foreigners too much preference in the privatization process; former 
prime minister Pawlak argued that he had tried his utmost to prevent foreign investors taking over Polish companies. Polish trade unions accuse foreign investors of employing 'slave labour' and taking away the 'family silver'. Russia has restricted the shares of assets that can be sold to foreigners and has made little attempt to withdraw discriminatory regulations that exclude foreign investors.

Of course, there is not only resentment. After all, the politicians of the CEE countries are well aware that they will need substantial flows of foreign direct investment to succeed in catching up with the West. The official policies of the CEE countries have been featured by significant moves towards liberalization. After the fall of the iron curtain, and partly even before, old communist legislation with most of its obstacles and hurdles was abolished. New foreign investment laws were set up early as 1988 in Hungary, and in 1991 in Russia, Estonia, Romania, Poland and Bulgaria. Albania and the Ukraine followed in $1992 .{ }^{6}$ Most importantly, the investment laws partly abolished the maximum stakes allowed to foreigners in East European enterprises that had been implemented by the communist regimes. In most cases, foreign investment no longer requires particular approval and registration is comparable to that of purely domestic firms. Several of the new laws include tax havens for foreign investment as well as preferential tariff rates. Nevertheless, the policy of liberalizing the rules for foreign direct investment has been rather schizophrenic. Since the reforms have often not gone far enough in the direction of removing all restrictions for foreign direct investment they have tended to appear halfhearted. Although major constraints have been lifted, other constraints have been imposed, ruling out foreign direct investment in many instances.

Impediments evolve from important details. In many countries foreigners are required to have special permits to buy land. This applies primarily to foreign investment that is not incorporated in the respective Eastern European country, but even incorporated subsidiaries may need a permit. The latter is the case, for example, in Poland. In Russia, foreign owned firms are, in practice, not allowed to own land

\footnotetext{
${ }^{6}$ For surveys see Goleva (1993) and EBRD (1994, Chap. 9).
} 
except where the land is acquired with the purchase of state owned enterprises. Major investment hurdles are also found in particular industry branches including insurance, banking, utilities and telecommunications, national defence and natural resources. ${ }^{7}$ Foreign direct investment in these branches is practically non existent in most countries.

Resentment against foreign investors may be even greater among the administrators than in legislation. Indeed, according to an OECD survey (1994, p. 133), foreign investors see bureaucratic and administrative issues as the most important constraints on a successful undertaking. Surprisingly, this not only applies to the less advanced economies of Bulgaria, Romania and Russia. Investors complain even more frequently about hurdles in Hungary of the Czech Republic, two of the most advanced CEE countries. ${ }^{8}$

\section{REASONS FOR THE RESENTMENT}

Much of the FDI has come from countries that were their enemies in World War II. Germany, the biggest direct investor, has invested nearly 50\% more in the CEE countries than France, the UK, and Italy taken together; Austria ranks third behind the US. Table 2 confirms a strong bias towards Germany and Austria. Poland and the Czech Republic, which are making special attempts to encourage US and British investors as a counterweight, are particularly delicate politically: large parts of their territories once belonged to Germans and to the German or Austrian states. Resentment against a return of German and Austrian investors is understandable.

\footnotetext{
${ }^{7}$ See EBRD (1994, Chap. 9).

8 OECD (1994, p.133-136).
} 
Table 2. Major investors in Eastern Europe (cumulated FDI to January 1995, US \$ mn)

\begin{tabular}{|c|c|c|c|c|c|c|c|c|c|c|c|c|c|c|c|c|}
\hline \multicolumn{17}{|c|}{ Host Country } \\
\hline 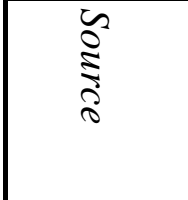 & 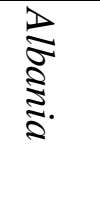 & 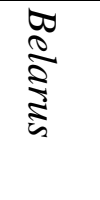 & 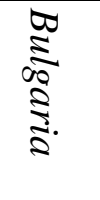 & $\begin{array}{l}\stackrel{2}{2} \\
\stackrel{2}{2} \\
\stackrel{2}{2}\end{array}$ & 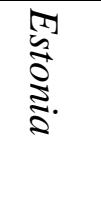 & 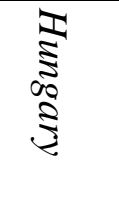 & $\underset{\mathfrak{\Omega}}{\stackrel{\Sigma}{\Sigma}}$ & 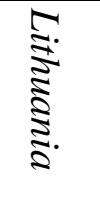 & $\frac{\mathfrak{s}}{\frac{3}{2}}$ & 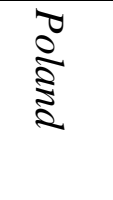 & 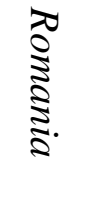 & 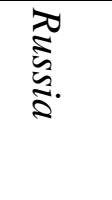 & $\frac{\sqrt[3]{2}}{2}$ & 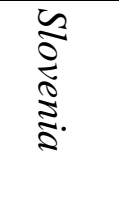 & 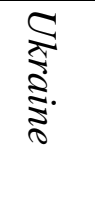 & $\underset{\mathbb{2}}{\stackrel{2}{Z}}$ \\
\hline Austria & n.a. & 6.7 & 22.0 & 216.6 & 6.7 & 1961.2 & 8.4 & 10.3 & 0,0 & 123.5 & 28.4 & 75.5 & 113.6 & 250.4 & 5.6 & 2828,8 \\
\hline Belgium & 1,0 & 0,8 & 36,3 & 188,6 & 0,1 & 205,9 & 0,2 & 6,2 & n.a. & 60,8 & 4,9 & 11,4 & 0,9 & 4,9 & 5,2 & 527,3 \\
\hline Canada & n.a. & 2,1 & n.a. & n.a. & 1,8 & 86,2 & 0,4 & 4,1 & 0,3 & 25,2 & 59,1 & 79,8 & 6,6 & 0,4 & 11,1 & 277,1 \\
\hline China & n.a. & 3,5 & n.a. & n.a. & 2,8 & 1,2 & n.a. & 0,3 & 0,0 & 0,9 & 5,9 & 169,5 & 0,1 & 0,1 & 2,3 & 186,7 \\
\hline Croatia & n.a. & 0,3 & n.a. & n.a. & n.a. & n.a. & n.a. & n.a. & n.a. & 0,3 & n.a. & 0,2 & 0,2 & 397,8 & 0,7 & 399,5 \\
\hline Egypt & n.a. & 0,1 & n.a. & n.a. & 22,6 & n.a. & n.a. & n.a. & n.a. & n.a. & n.a. & 0,1 & 0,0 & 0,0 & 2,4 & 25,2 \\
\hline Finland & n.a. & 2,9 & n.a. & n.a. & 58,0 & 21,6 & 30,5 & 2,2 & n.a. & 21,8 & 0,2 & 87,9 & 0,0 & 0,0 & 0,2 & 225,3 \\
\hline France & n.a. & 2,9 & 12,1 & 355,6 & 0,3 & 507,7 & 0,2 & 1,3 & 0,0 & 105,3 & 104,2 & 61,1 & 38,5 & 178,4 & 6,6 & 1374,1 \\
\hline Germany & 9,6 & 56,7 & 178,2 & 1113,0 & 8,6 & 2197,1 & 22,6 & 44,9 & 2,8 & 631,3 & 97,6 & 139,7 & 123,5 & 194,9 & 64,0 & 4884,4 \\
\hline Greece & 37,8 & 0,1 & 33,1 & n.a. & 0,1 & 8,4 & n.a. & 0,0 & 0,8 & 14,3 & 26,5 & 14,2 & 0,2 & n.a. & 2,3 & 137,8 \\
\hline Italy & 74,0 & 20,5 & n.a. & 92,5 & 3,1 & 465,8 & 1,3 & 1,5 & 5,1 & 166,3 & 101,1 & 45,3 & 14,1 & 125,5 & 8,3 & 1124,3 \\
\hline Netherlands & n.a. & 4,0 & 57,4 & n.a. & 4,6 & 1111,1 & 15,5 & 3,6 & 0,0 & 371,3 & 78,5 & 45,6 & 36,9 & 7,4 & 7,7 & 1743,6 \\
\hline Poland & 4,0 & 53,5 & n.a. & n.a. & 0,5 & n.a. & 1,6 & 10,0 & 0,0 & - & 2,3 & 10,8 & 0,6 & n.a. & 11,6 & 95,0 \\
\hline Russia & n.a. & 0,1 & 2,9 & n.a. & 45,4 & n.a. & 19,0 & 12,4 & 0,4 & 21,5 & 0,6 & - & 0,3 & 1,6 & 16,6 & 120,7 \\
\hline Sweden & n.a. & 3,4 & n.a. & n.a. & 45,9 & 110,2 & 9,1 & 52,7 & 3,7 & 75,9 & 14,4 & 20,0 & 17,4 & 0,2 & 3,5 & 356,5 \\
\hline Switzerland & n.a. & 9,3 & 50,6 & 136,7 & 2,2 & 383,1 & 18,4 & 8,4 & n.a. & 154,2 & 48,0 & 878,4 & 4,2 & 53,5 & 17,2 & 1764,3 \\
\hline$U K$ & n.a. & 8,3 & 17,6 & n.a. & 6,9 & 419,1 & 73,7 & 8,6 & 0,0 & 147,8 & 61,9 & 42,5 & 14,6 & 5,3 & 29,2 & 835,6 \\
\hline$U S$ & 2,0 & 44,7 & 25,1 & 651,1 & 17,0 & 1331,4 & 44,7 & 37,2 & 1,9 & 653,1 & 103,0 & 854,6 & 79,7 & 3,3 & 79,3 & 3928,2 \\
\hline other & 15,6 & 67,0 & 31,9 & 323,3 & 87,4 & 1097,7 & 70,6 & 38,3 & 9,6 & 266,2 & 490,5 & 478,5 & 100,4 & 29,9 & 93,1 & 3200,1 \\
\hline total & 144,0 & 286,9 & 467.2 & 3077.4 & 314,0 & 9907.7 & 316,2 & 241,9 & 24.7 & 2839.7 & 1227.1 & 3015.4 & 551,7 & 1253,6 & 366.9 & 24034,4 \\
\hline
\end{tabular}

Source: UN/ECE (1994, 1995).

Note: Albanian data to Jan. 1994. 
A similar resentment, with a different focus, exists in Slovenia and Croatia, historically under Italian sway. Both Croatia and Slovenia forbid Italian land purchases, but encouraged German investors as a counterweight.

Resentment also reflects a fear that FDI will spoil the privatization process. Direct investment in the CEE countries typically does not come in the form of greenfield investment, but requires the sale of existing firms. The sale, it is feared, will ocur at firesale prices and give rise to the family silver problem. Precious assets will be handed over to foreigners who can make overly favorable deals that exploit the special circumstances under which the sales take place.

The bias against greenfield investment is unusual, for, on a worldwide basis, investment in existing firms accounts for no more than $30 \%$ of the total flow of direct investment. ${ }^{9}$ The privatization process explains the difference. Speed, lower investment cost, easier integration into existing trade networks, lower administrative hurdles and simply the abundance of assets supplied have contributed to a close link between privatization and FDI from the start. Foreign investors have always tried to participate in privatization and have been able to outbid domestic interests wherever they were allowed to use their financial muscle. In 1990, 95\% of Hungarian privatization revenues came from foreign investors (Lane, 1994). From 1988 to 1992, 45\% of all funds directly invested in Poland were connected with privatization. In the Czech Republic the figure was as much as $87 \%$ (EBRD, 1994). On average, privatization accounted for $60 \%$ of FDI in the CEE (UNCTAD,1995a and 1995b). Table 3, which applies to project cases rather than values, confirms that FDI has been concentrated not in greenfield investments but in acquisition of, or joint ventures with, existing enterprises.

\footnotetext{
${ }^{9}$ See Healey and Palepu (1993, p.231). An exception was the foreign direct investment received by the US of which 90\% was acquisition in the period from 1988 through 1990. See Lipsey (1993, p.141)
} 
Table 3. FDI investment by type (\% of cases involving existing firm not greenfield investment)

Czech Republic Hungary $\quad$ Poland Russia

67

60

37

63

Source: OECD (1994). Sample of 162 firms.

\section{ECONOMIC EXPLANATIONS FOR THE FAMILY SILVER PROBLEM}

While some reasons for resentment of FDI are unfounded, overstated or unchangeable, the family silver problem is a matter of real concern. There are several reasons why privatization offers overly favorable opportunities to western investors and why sales of existing assets are not a good way of attracting FDI.

One reason is information asymmetry. Western investors may have better knowledge than privatization agencies about the true investment opportunities provided by the assets, and may therefore be able to outwit the agencies. While the information asymmetry cannot easily be avoided, we will show that there are ways to mitigate its consequences. A second reason is endogeneity of asset prices. Mass privatization is not the same as the marginal British or French privatizations of the 1980s. The latter could be managed from a business economics perspective, given the price level of competing assets and given the interest rate. Mass privatization, however, requires more than business economics, because endogenous changes in market conditions have to be taken into account.

The most obvious change in market conditions results from the law of demand, the fact that price falls when the quantity supplied increases. If privatized assets are not exceptions to the law of demand, mass privatization must depress asset prices and create a windfall gain for the purchasers of these assets. The German experience with the Treuhand sales showed this very clearly. Leaving aside the agency's subsidies, its revenue from sales was hardly more than 50 billion DM, much less than the 600 billion DM revenue it had expected initially and less than a quarter of what a conservative 
estimate of just the value of the land sold would have suggested (Sinn and Sinn, 1991). Endogenous erosion of asset prices may not be a problem if domestic residents get the windfall gain, as in the German case, but it is hardly acceptable for the CEE countries if it is shared by foreigners. There are at least three reasons why the law of demand applies to privatized assets and why there is a windfall gain.

First, the asset risks are highly correlated and belong to the same risk class. The higher the supply the lower the price must be if the expected rate of return to investors is to increase. The increase in the expected rate of return is necessary to induce investors to absorb more and more of the CEE assets into their portfolios.

Second, investors may not have unlimited access to the international capital market. They may be credit constrained and find it difficult to raise the equity capital needed to finance the investment at short notice. The problem may be reduced if the privatization is slow enough to make it possible for the required funds to be accumulated through profit retention. However, when mass privatization is carried out in a short period of time, say a year or two, there is a microeconomic stock flow problem which may result in a sharp erosion of asset prices. ${ }^{10}$

Third, there may even be a macroeconomic stock flow problem: no matter how high the domestic interest rate, the flow of aggregate savings may be insufficient to finance in a short period the sale of the entire stock of state assets, except at distress prices or unless substantial foreign financing takes place. Limits on the latter lead to rises in domestic interest rates that further reduce asset values. This effect may still operate when national capital markets are fully integrated if many transition economies privatize simultaneously. The capital demand may then be large relative even to the global market. Even though we focus on CEE countries, one should not forget that similar events are occuring in China and elsewhere.

\footnotetext{
${ }^{10}$ Even large private investors may be credit constrained. In 1994 Volkswagen, for example, announced the cut-back of its investment plan for Skoda. The reason which VW gave was not that Skoda was not profitable enough but that losses of VW's Spanish subsidiary Seat made finance scarce within the multinational ( Financial Times, 24 October, 1994).
} 


\section{THE PARTICIPATION MODEL}

Despite reservations about FDI, it is too important and too useful for potential recipient countries to eschew it completely. Direct investment brings risk bearing equity capital and knowhow, opens up new markets in the West, provides the East with modern products that help raise living standards, and quickly imports a responsible and knowledgeable management. FDI is an indispensable ingredient in a successful strategy for economic growth and prosperity in the CEE countries. The participation model offers a way to realize these advantages without arousing the fears identified in previous sections.

The essence of this model is a joint venture contract. The government brings its existing assets, the foreign investor adds the necessary restructuring capital and knowhow. Each receives shares for whatever it contributes. No existing assets are sold. The government defines the necessary investment volume. Share values are determined in a competitive bidding process where the investor has to specify the value he places on the existing assets brought by the government. The government selects the investor with the highest value on the existing capital. Ideally the values of the shares retained by the government and those given to the investor will then reflect the true values of the respective contributions. The auction process is incentive compatible: the most competent bidder wins the auction even though the government is unable ex ante to monitor its ability. We study details of the auction process in section 7.3 .

In a second step the retained shares are given to the domestic population and employees. ${ }^{11}$ Shares for the general population could be channelled through a mutual fund to diversify the portfolio risk. The Czech voucher method would be a possible way of organizing the distribution process.

In principle, shares could also be retained for use in financing the government budget rather than given to the public. However, such a solution would miss the opportunity of creating wealth for the domestic population. By its very definition,

11 See Boycko, Shleifer and Vishny (1994) for the importance of broad participation for the acceptance of privatization. 
communism could not allow people to accumulate private wealth. All accumulation was carried out by the State, and people paid for this by not receiving some of their wages. A privatization process where the "peoples' wealth" - however little it may be is not returned to the people may not only be felt as unjust, it may also be inefficient. A successful start in a capitalist market economy requires a broad group of people endowed with a nucleus of wealth, from which small private business can grow. It could be unwise not to take the opportunity of removing unnecessary hurdles for setting up new business and getting the economy going. ${ }^{12}$

How control rights are allocated is open to debate. The foreign investor will probably only be interested if the rights of domestic share owners, public or private, are limited to the bare essentials of protecting their equity: silent ownership by the domestic share owners will best stimulate FDI. The foreign investor could receive full responsibility for restructuring the former state firm to face international competition. Even when the winning foreign investor is allocated less than $50 \%$ of the shares, it could obtain control over management of the assets.

The investor's incentives to run the firm efficiently are largely independent of the fraction of shares it owns: since it earns a fixed percentage of the total flow of dividends, it will want to maximize the profit stream on which dividend are based. Admittedly, there is a latent moral hazard problem. Some of the costs of management may not show up in a pecuniary form and may thus not be included in the firm's visible cash flow. To reduce the relative importance of this problem, the participation model could be limited to cases where the investor can be endowed with a substantial fraction of the shares, large enough to dwarf the importance of non-pecuniary aspects in the management problem.

The participation agreement could, in principle, be indefinite, just like the 'agreement' between the shareholders of any joint stock company. However, the

\footnotetext{
12 It could be argued that it would be better for the government to retain the assets, because their returns offer a distortion free source of finance for public goods. The problem with this argument is that it overlooks the basic asymmetry in the wealth distribution between the government and the private sector after the fall of communism. While ex-communist governments possess nearly all the economy's wealth, private individuals are paupers, unable to invest and unable to borrow. A market economy cannot start to grow out of such a situation.
} 
management could have the right to issue new shares for further equity injections in the future, and this, of course, would then automatically alter the fraction of dividends earned by the public. Section 8 will discuss this in more detail.

\section{ADVANTAGES OF THE PARTICIPATION MODEL}

The participation model is located between cash sales of state assets and voucher privatization, between the 'German' and the 'Czech' ways. The German way solves the problem of corporate governance but bypasses the ownership right of the general population. The Czech way maximizes distributional justice but it fails to create a dominant shareholder who will establish an efficient management. The participation model combines the two advantages. It establishes a responsible management and maximizes the wealth to be distributed to the public. The public gains more than with a voucher privatization because the investors who are brought in have the knowledge and restructuring capital to augment the value of the existing assets. And the disadvantages of cash sales spelled out above can largely be avoided.

\subsection{Mitigating the stock flow problem}

Investors need no funds to pay the privatization agency for taking over existing assets. 'Payment' occurs as dividends later to the host country, which is strictly preferable if there is a shortage of funds available for direct investment today. The microeconomic variant of the stock flow problem will be reduced because more credit-constrained investors will be able to participate and because more resources will be available for investment that augments the firm's capital stock. The macroeconomic variant of the stock flow problem will be mitigated if many of the privatization projects of the CEE countries follow the participation model. Investors need fewer funds, the situation in the capital market is less tight, the interest rate is lower, and the present value of the cash flow is larger. Investors are willing both to cede a higher present value of dividends to the host countries and to undertake more restructuring investment.

The macroeconomic stock flow problem could reappear if governments compensate for the lack of immediate privatization revenues by borrowing in the 
capital market. However, in practice governments of transition economies are likely to be credit constrained. The lack of funds will result in a reduction of public expenditure or an increase of taxes which will crowd out private expenditure. In either case, a lower burden will be placed on the capital markets than in the case of cash sales.

\subsection{Earning a risk premium}

Paying the government with dividends means not only that the investor pays later but also that it pays only if, and to the extent that, the enterprise turns out to be successful. The host country shares the risk involved with the enterprise. As a risk averse investor finds this attractive, it will pay a risk premium to the privatization agency by putting a high value on the existing capital. Appendix B confirms that the participation auction generates a higher revenue for the government than a cash auction.

\subsection{Joining the winner}

Apart from earning a risk premium, a participation contract allows the host country to share the as yet unknown knowhow that the foreign investor is likely to contribute. Cash auctions are very problematic in a situation where an efficient foreign investor competes with less knowledgeable domestic investors: the foreign investor will win by bidding just a little more than his domestic competitors without having to reveal the true value of the enterprise. This is the justified fear of being outwitted by clever investors. A participation auction mitigates this problem. The government shares in the true value of the enterprise whenever it is revealed through receiving the dividends actually earned. The risk of losing a lucrative enterprise for a trifle is reduced if the government keeps its stake in the firm.

This point is elaborated more formally in Appendix C. The intuition is illustrated by the example in Table 4. The government wants to sell a car factory. It is known to the government that a potential investor has to rebuild certain run-down sections of the factory and retire old debt. Let the combined total restructuring cost be $\$ 400 \mathrm{mn}$. Suppose only two investors show any interest, and have different abilities to market the factory's output. Investor 1 expects to produce $\$ 900 \mathrm{mn}$ of future discounted 
dividends from the firm, investor 2 expects only $\$ 600 \mathrm{mn}$. Let both investors be risk neutral. Taking restructuring cost into account, this defines maximum bids of $\$ 500 \mathrm{mn}$ and $\$ 200 \mathrm{mn}$, respectively. These bids are private information to each investor and unknown by the government. Provided the government definitely sells, in all standard cash auctions investor 1 wins and pays a price equal to (or marginally above) investor 2's willingness to pay. ${ }^{13}$ In Table 4 a standard cash auction will see investor 1 marginally outbid investor 2's maximum bid of \$200 mn, leaving investor 1 a buyer's rent of $\$ 300 \mathrm{mn}$, and giving the government a revenue of $\$ 200 \mathrm{mn}$.

Table 4. More revenue from participation bids

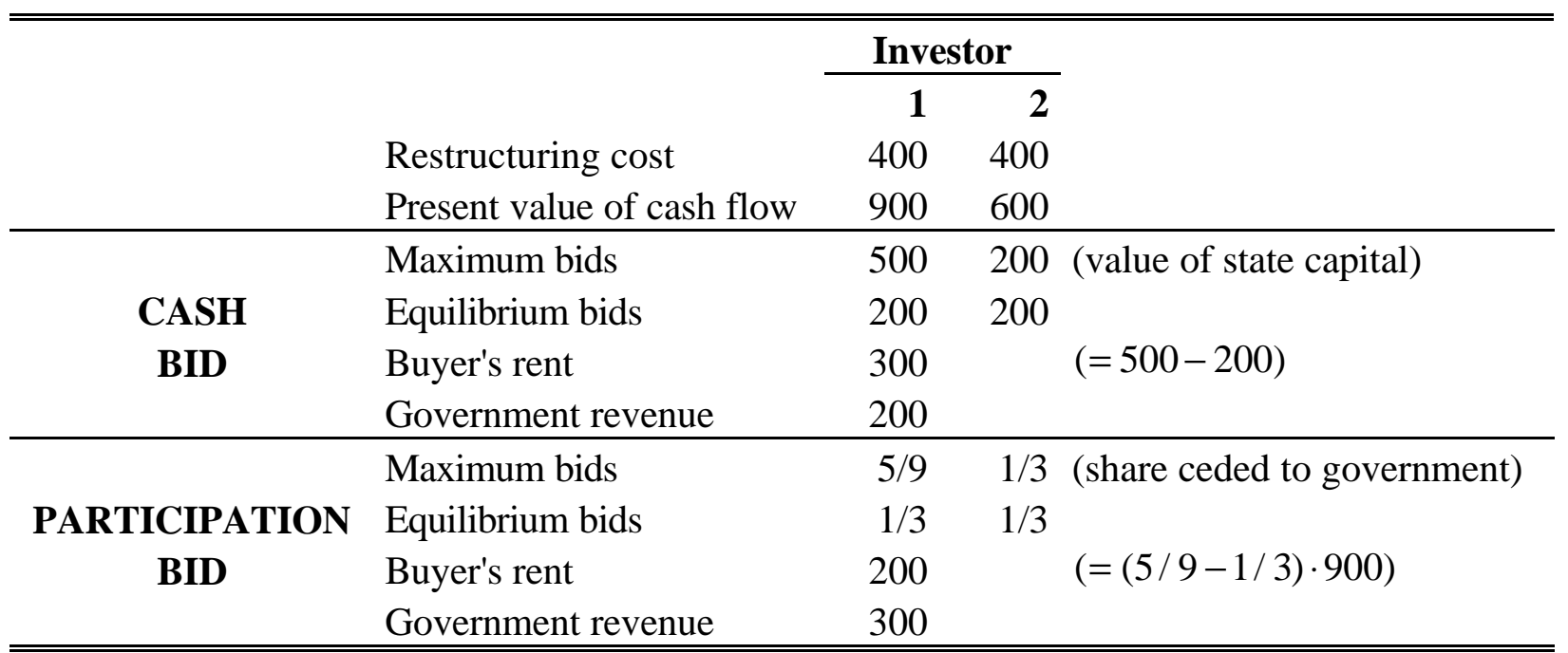

Now suppose the government conducts an auction via a participation contract in which the winning bidder must contribute $\$ 400 \mathrm{mn}$ of restructuring investment; bids are for the the proportion of future dividends ceded to the government. Investor 2's maximum bid is $1 / 3$, since $2 / 3$ of his expected future dividends ( $\$ 600 \mathrm{mn}$ ) equal the necessary restructuring investment of $\$ 400 \mathrm{mn}$. To outbid investor 2 , investor 1 must

13 This holds for a Dutch auction, an English auction, a first price sealed bid auction, or a second price auction ( McAfee \& McMillan, 1987; Wolfstetter, 1996). With risk averse bidders, the English auction yields a higher expected revenue than the second price auction. Maskin (1992) evaluates different types of cash auction for privatization in CEE countries. Auction theory tells us that the auctioneer may increase the expected revenue above the second winner's bid by setting a reservation price (McAfee \& McMillan, 1987). However, this requires that the auctioneer must be able to commit to keep the asset if the highest bid is below the reservation price which is very questionable in Eastern Europe's privatization programmes. 
cede marginally more than $1 / 3$ of future dividends to the government. The government receives $1 / 3$ of $\$ 900 \mathrm{mn}$ which is $\$ 300 \mathrm{mn}$, and investor 1's rent is only $\$ 200 \mathrm{mn}(2 / 3$ of $\$ 900 \mathrm{mn}$, less $\$ 400 \mathrm{mn})$.

Government revenue is $\$ 200 \mathrm{mn}$ in the cash auction, but $\$ 300 \mathrm{mn}$ in the participation auction. The latter enables the host country to participate in the winner's future dividends. A cash auction means joining the loser, a participation auction means joining the winner. The host country gains by choosing a participation auction. The result is an application of a fundamental result in auction theory first proved by Hansen (1985). ${ }^{14}$ If the seller can infer ex-post the purchaser's valuation of the asset, he is always better off if bids are made in terms of this valuation. The participation method makes use of this wisdom.

The magnitude of the excess revenue generated by the participation contract will depend on the ratio of the present values of dividends as expected by the best and second best bidders. This ratio may be close to one if there are a number of similar foreign direct investors who compete. In this case the two kinds of auctions are equivalent. However, when the bidders are very different, as will be the case when a foreign direct investor competes with domestic investors, the ratio may be much larger than one, and so a large gain can be expected from using the participation auction instead of a cash auction. ${ }^{15}$ The participation makes better use of the family silver and thereby overcomes some of the political resentment against FDI.

\section{CAVEATS, PROBLEMS AND PROBLEM SOLUTIONS}

While the participation auction has fundamental advantages over a cash auction, it is of course not fully robust with regard to all kinds of problems.

\footnotetext{
${ }^{14}$ See also McAfee \& McMillan (1986), Crémer (1987), Samuelson (1987), and Riley (1988).

15 Note that with asymmetric bidders the revenue equivalence of cash auctions breaks down: the firstprice sealed-bid auction can yield both higher and lower revenues than a second price auction or an English auction (McAfee \& McMillan, 1987).
} 


\subsection{Transfer pricing}

The participation contract works best when information asymmetries diminish over time. In the example of Table 4, implicitly the government was able to monitor ex post the surplus extracted by the foreign investor. When these occur only via dividends this may be reasonable; but they can also be extracted via "costs" whose value is articificially inflated in ways that the host finds difficult to monitor. One example is transfer pricing. A foreign parent company having a joint venture with a CEE country may supply the joint venture with overpriced intermediate goods and thus repatriate profits which circumvent the host country's participation. Both Volkswagen's subsidiary in the Czech Republic (Skoda) and Fiat's subsidiary in Poland (Polski Fiat) have been blamed for overpricing automobile parts delivered by the parent companies. ${ }^{16}$

This is a serious problem, well known in the literature on international tax arbitrage. The fear of receiving a bad reputation is a potential safeguard against transfer pricing, but it would certainly be better to implement western-style auditing and control systems combined with sufficiently strong rights of the minority shareholder to prevent fraudulent acts. The arm's length principle, which requires the payment of market prices for trade flows between the parent and its subsidiary, could be used as a yardstick. ${ }^{17}$ To date, few CEE countries have yet legislated the arm's length principle (OECD,1995).

Even where the arm's length principle cannot yet be implemented, the participation contract retains important virtues. One relates to the government's incentive to exploit the firm with a confiscatory tax system once the investment is made. ${ }^{18}$ This incentive mirrors the investor's incentive to exploit the host country's shareholders, but unlike the latter, it is weaker the larger the host country's participation rate. Clearly the participation of shareholders from the host country is a

16 See, e.g., Business Central Europe, February 1995, pp. 52-54.

17 Distorted trade and investment decisions through profit shifting activities are described in Kant (1995) and Weichenrieder (1996). Not all profit shifting activities can be ruled out by auditing and control mechanisms: in monopolistic markets, output decisions can serve as profit shifting devices. See Keen (1991) or Weichenrieder (1995).

18 This is the hold-up problem studied by Eaton/Gersovitz (1983) and Bond/Samuelson (1989). 
safeguard against exploitation, since these shareholders would use their voice and electoral power to tame their government. ${ }^{19}$ (See section 9 for a further analysis of the tax problem.)

Another virtue results from the possibility of capitalizing the dividend loss from false transfer pricing. To demonstrate, suppose the two highest bidders have the same possibility of extracting a certain fraction of the firm's profits by overpricing the parts they deliver. If both contracting parties know this, the equilibrium will be characterized by correspondingly higher participation rates for the government, and the discounted value of revenues will not be affected..$^{20}$ Even if the fractions of profits which the two bidders can shift differ, there will be no problem provided the government anticipates these fractions correctly and selects the bidder who promises the highest returns. Only unknown abilities of using transfer pricing tricks create a problem. This is the issue of selection efficiency which we discuss next.

\subsection{Selection efficiency}

Another important consideration for the evaluation of auctions is to which extent they ensure that the most efficient investor is picked. In the auction settings so far discussed, the most efficient investor will in fact win. Adding further real world problems may destroy this property, with repercussions on expected privatization revenues. In general, it is unclear whether cash auctions or participation auctions enjoy a higher selection efficiency.

However, if investors exhibit different degrees of risk aversion or differ primarily with regard to the credit constraints they face, the participation contract will dominate. Credit constraints are a severe problem for the transition countries whose capital markets have not yet matured. In the presence of credit constraints a cash auction will pick the most liquid bidder, not typically the bidder with the most promising restructuring plan.

19 For a related argument in an asymmetric information framework see Konrad (1996).

20 See Appendix C. 
The Treuhand privatizations in East Germany demonstrated this very clearly. While the old managements of the communist firms often had the best ideas and the necessary knowledge of local conditions to rescue their firms, it was typically liquid western investors who made the deal. All too often these investors bought the firms for extremely low prices, aiming at no more than selling the assets and closing the firms.

It would be dangerous for the transition countries to adopt the Treuhand policy: they would deprive competent domestic bidders of their fair chance of taking over the assets to be privatized and forego the chance of generating substantial privatization revenues.

\subsection{Investment incentives}

Do participation auctions inhibit investors' incentives to contribute capital to the firm, since the host country participates in the returns on this capital? The answer is no. Neither the initial capital contribution of the foreign investor nor any future investment financed from retained earnings creates a problem. The initial capital contribution is part of the deal, and the host country participates in the investment financed with retained earnings in proportion to its participation in the dividends generated thereby. The latter is particularly important in the light of the fact that normally a firm's equity capital is generated by profit retentions. It is a fundamental virtue of a joint stock company that the majority shareholder's financial and real investment decisions are independent of the existence of a minority shareholder.

In principle one could dream up alternatives to the participation contract where the government receives future payments contingent on particular events, for example profits exceeding a certain threshold level. However, typically such schemes would distort the majority shareholder's investment decision, since the proportion at which the government contributes to the investment differs from the proportion at which it participates in the return. The participation contract avoids this problem.

A difficulty may arise if future investment is financed with new equity injections. If this equity is provided by the foreign investor, it should receive more shares in the firm, but it is unclear how these shares should be evaluated. If the shares happen to be sold 
at their 'true' intrinsic value, there is no distortion in the investment decision. However, the incentive to invest is too strong or too weak, if the investor pays too little or too much for the shares. The difficulty can be avoided, though, if all owners receive new share entitlements. The host country can either use its entitlements and contribute capital according to its participatory share or can sell them at a competitive price to its partner or to outsiders. In either case, the incentive to invest is undistorted.

It may not be sensible to make a commitment to future equity injections by the investor part of the initial deal, as was done when VW joined Skoda. Promises of future equity injections lack credibility and are hard to be enforced. The outside investor may have an incentive not to keep these promises if the investment turns out to be less profitable than foreseen. Initial equity injections which are part of the deal and future equity injections via share entitlements are better alternatives.

The above discussion suggests that there are few problems with investment incentives as long as these investments are made in terms of physical capital. A more serious incentive problem may arise if the investment takes the form of the investor's knowhow. In this case the foreign investor could be allowed to ask for a reasonable compensation. Within multinational corporations license fees and royalties are a standard, albeit imperfect, way of coping with this problem.

\subsection{Bargaining about more complicated contracts}

Our discussion thus far has assumed a formal competitive bidding process. Such a formal process will often be difficult to implement since the government's decision will depend on more aspects of the deal than the participation rate. For example, the government may have employment or environmental objectives to balance against the objective of maximizing revenues. It seems to us that the participation contract is preferable to cash sales even under such circumstances. If the government wants a cash price, the foreign investor has an incentive to hide the firm's true opportunities in order to receive a better price. However, if the government insists on keeping a stake, the investor has an incentive to reveal his knowledge about investment opportunities. More than that, it is in its interest to exaggerate the firm's opportunities to convince 
the government that high future profits justify a somewhat smaller government stake. Given that it is probably more difficult for the government to reinvent the investor's business plan than to check a too optimistic one, the insistence on a participation stake seems to put the government in a more favorable position.

\section{PARTICIPATION VERSUS TAXATION}

While cash sales remain an unattractive method of combining direct investment with privatization, the participation model is not the only way to overcome the political resentment. A policy of selling assets at favourable prices and taxing their returns may appear an attractive alternative. Withholding taxes on repatriated profits seem particularly well suited for compensating the disadvantages of a fire sale privatization.

In economic terms, a policy of giving away state owned assets and charging a withholding tax is very similar to the participation model. The government contributes its own assets and participates in the dividends, just as with the participation model. The similarity between dividend taxation and holding a silent partnership has often been discussed in the literature, and it once induced the Meade Committee (1978) to propose a dividend tax as the only tax on company profits, arguing that most other ways of taxing company profits would create larger distortions.

At first sight the tax-cum-give-away strategy even seems superior to the participation model when international double taxation agreements are taken into account. Often these agreements allow the investor to subtract foreign withholding taxes from its own tax claim at home. A CEE government can exploit this effect by charging a dividend tax at, or slightly below, the host country's profit tax rate without fear of diminution of investors' enthusiasm or consequent privatization revenue. 
Table 5. The treatment of repatriated profits from CEE countries

\begin{tabular}{|c|c|c|c|c|c|}
\hline Source & Austria & Germany $^{\mathrm{a}}$ & Canada & UK & US \\
\hline Armeniab $^{\mathrm{b}}$ & exemption & tax credit & tax credit & tax credit & tax credit \\
\hline Aserbaijan $^{b}$ & exemption & tax credit & tax credit & tax credit & tax credit \\
\hline Bulgaria & exemption & exemption & tax credit & tax credit & tax credit \\
\hline Belarus $^{b}$ & exemption & tax credit & tax credit & tax credit & tax credit \\
\hline Croatia & exemption & exemption & tax credit & tax credit & tax credit \\
\hline Czech Republic & exemption & exemption & exemption & tax credit & tax credit \\
\hline Estonia & exemption & tax credit & tax credit & tax credit & tax credit \\
\hline Georgiab $^{b}$ & exemption & tax credit & tax credit & tax credit & tax credit \\
\hline Hungary & exemption & exemption & exemption & tax credit & tax credit \\
\hline Kazakhstan ${ }^{b}$ & exemption & tax credit & tax credit & tax credit & tax credit \\
\hline Kyrgyzstan $^{b}$ & exemption & tax credit & tax credit & tax credit & tax credit \\
\hline Latvia & exemption & tax credit & exemption & tax credit & tax credit \\
\hline Lithuania & exemption & tax credit & tax credit & tax credit & tax credit \\
\hline Macedonia & exemption & tax credit & tax credit & tax credit & tax credit \\
\hline Moldova $^{b}$ & exemption & tax credit & tax credit & tax credit & tax credit \\
\hline Poland & exemption & exemption & exemption & tax credit & tax credit \\
\hline Romania & exemption & exemption & exemption & tax credit & tax credit \\
\hline Russia $^{b}$ & exemption & tax credit & tax credit & tax credit & tax credit \\
\hline Slovak Republic & exemption & exemption & exemption & tax credit & tax credit \\
\hline Slovenia & exemption & exemption & tax credit & tax credit & tax credit \\
\hline Tajikistan $^{\mathrm{b}}$ & exemption & tax credit & tax credit & tax credit & tax credit \\
\hline Turkmenistan ${ }^{b}$ & exemption & tax credit & tax credit & tax credit & tax credit \\
\hline Ukraine $^{b}$ & exemption & exemption & tax credit & tax credit & tax credit \\
\hline Uzbekistan $^{\mathrm{b}}$ & exemption & tax credit & tax credit & tax credit & tax credit \\
\hline
\end{tabular}

Sources: Bilateral tax treaties, OECD (1991), BMF-Schreiben, January 4, 1993; Korn/Debatin (19821995); national German tax law.

an general, German double taxation treaties exempt dividends received from foreign incorporated subsidiaries. The reason why the double taxation treaty with the former USSR deviates from this norm is that Germans could not participate in USSR corporations at the time the treaty was signed.

${ }^{b}$ The republics of the CIS will continue to be bound by the former USSR as long as new treaties are not in force. Estonia, Latvia, and Lithuania do not consider themselves bound by former USSR treaties. (See International Bureau for Fiscal Documentation, Central and Eastern European Tax Reports, 30 March 1992.) Austria, Belgium, Denmark, Finland, France, Germany, India, Japan, the Netherlands, Switzerland, and the UK have announced they will continue to respect existing agreements with the USSR. Germany and Ukraine, however, concluded a new treaty on 3 July 1995 which overrides the old agreement. 
Table 5 gives an overview of the double taxation agreements between the CEE and CIS countries and five important investor countries. With the exception of Austria and some countries in which German and Canadian investors are engaged, the credit method clearly dominates the existing double taxation agreements.

Contrary to first appearances, however, the double taxation agreements do not really lend support to a cash privatization strategy. There are a number of reasons why this is so. The first is that the EC forbids withholding taxes for its members. ${ }^{21}$ For all those countries wanting to become members in the foreseeable future, the possibility of participating permanently in the profits of the privatized assets by imposing withholding taxes does not exist.

Second, the gain from the imposition of withholding taxes is constrained by the fact that the residence country does not credit any excess of foreign taxes over its own tax claims. Thus the crediting possibilities will typically be exhausted independently of the privatization strategy. Tax credits therefore do not imply a dominance of cash sales over the participation model. ${ }^{22}$

Third, a withholding tax would have to be the same for all investors, regardless of how much capital they contributed and how much they gained from receiving state assets at fire sale prices. As the tax rate cannot be tailored to the individual investor, it has to be low enough to make the worst of the investment projects profitable. It follows that it is unable to generate a revenue comparable to the participation contract which is tailored to each individual situation.

Fourth, dividend taxes suffer from the lack of a credible commitment by the government and are thus an unattractive alternative for the investors. The government can always raise these taxes in future. In contrast, an individual joint venture contract would typically be protected by the new constitutions of the reforming countries. The participating share in a joint venture contract cannot as easily be altered as a tax rate. It provides a greater security for the investor.

21 See Directive 90/435 EEC (Parent-Subsidiary Directive).

22 Welfens (1994, p. 158) suggests a capital gains tax to reduce investors' windfall profits which can be caused by privatization. Note, however, that a capital gains tax is a residence based tax. It therefore cannot be applied to foreign investors. 


\section{LEARNING FROM THE CHINESE EXPERIENCE?}

Participation contracts of various kinds have frequently been used in China. As early as 1979, China opened its borders for FDI. Still committed to the principles of socialism, a complete take-over of existing state-owned firms by foreigners was ideologically unacceptable for the Chinese government. However, joint ventures with existing firms were allowed, and wholly-owned foreign enterprises have been feasible in the form of greenfield investment (Zhang \& Thoburn, 1995); takeovers of Chinese firms have been possible only since 1995 .

Various studies have discussed the problems facing the Chinese joint ventures, and at first sight these seem to place doubt on the usefulness of participation contracts. Among other things, Chinese partners were blamed for showing short-term attitudes, incompatible with a sound and stable development of the firms (Thoburn, Leung, Chau and Tang, 1990). These attitudes may have resulted from socialist ideology, which saw FDI as a temporary compromise on the long way towards a communist society. Ideology also may have been a reason why joint ventures have been required to have a finite life. Before 1990 the duration of joint venture contracts typically was no more than 15 to 30 years, today the average duration is about 50 years. Another problem is related to the multitude of goals that Chinese partners imposed on the joint ventures. Apart from trying to import foreign capital and knowhow, there has always been pressure on foreign firms to earn foreign exchange by way of exporting goods to other countries. Numerous examples show that tedious renegotiations were necessary if the performance of a joint venture did not meet the government's expectations with respect to the transfer of knowhow and the earning of foreign currency.

Despite these problems, Chinese joint ventures have been a success story. A survey of 50 Hong Kong investments in China indicates that the success of investment does not vary systematically between joint ventures and firms that are wholly-owned by foreigners (Thoburn, Leung, Chau and Tang 1990), and a study by Luo (1996) 
shows that joint ventures even perform better: the average return on equity of Chinese joint ventures is roughly $25 \%$ higher than that of wholly-owned foreign firms.

The Chinese joint ventures have turned out to be a useful vehicle for FDI. In all likelihood they would have performed even better had the participation contract discussed in this paper been used. Unlike the Chinese joint venture contract, the participation contract establishes a clear responsibility for the western investor and it is of unlimited duration. This should help avoid the tedious renegotiations about external company goals and raise the incentives to care about long-term investment.

\section{CONCLUSIONS: WHERE THE PARTICIPATION CONTRACT SHOULD BE APPLIED}

We have shown that CEE countries have exerted surprising resentment against FDI, some of which reflects the justified fear that foreigners participate in cash privatization at overly favorable conditions, concentrating on speculative purchases of existing firms rather than greenfield investment. Much of the concern with direct investment can be overcome by using the participation model that we propose. It avoids the family silver problem, leaves more funds for genuine investment, and generates higher privatization revenue. It is superior to voucher privatization by helping to establish a dominant shareholder thus resolving the problem of corporate governance.

It would have been ideal if the participation model had been used in earlier stages of the privatization process. Today, a significant fraction of the privatization tasks has already been completed. This is particularly true in the Czech Republic, Estonia, Slovenia, Hungary and Moldova. However, there are many countries where privatization has yet to go far, and there are a few countries where virtually nothing has been achieved. The latter group comprises Azerbaijan, Kazakhstan, Turkmenistan and the Ukraine. The former includes Albania, Armenia, Belarus, Bulgaria, Georgia, Kyrgyzstan, Latvia, Lithuania, the Slovak Republic, Romania and, most prominently, Poland and Russia. In Poland and Russia, aversion to selling existing assets to foreigners has been particularly strong. These two countries could be the primary focus 
for a reconsideration of FDI. The participation model, by increasing the scale of FDI, may open the road to a more successful development.

The participation model does not have to be confined to the first step of the privatization process. Since this model describes a joint venture with a foreign investor in which the existing assets are kept in the hands of the host country, it may also be suited for a second privatization step where the new private share owners invite a foreign partner to manage their firm. The partner would receive shares in exchange for the new capital and knowhow. Representatives of the existing private owners, whether the management or a private investment fund, could act like the privatization agency. They could invite restructuring bids and select the best partner according to the rules described in this paper.

Countries like the Czech Republic or Romania, which have used the voucher method, could now switch to the participation model to solve the problems of a weak corporate governance and a shortage of capital which still exist after privatization. The same is true for the Russian firms whose shares largely went to the workers. Worker cooperatives cannot really be considered feasible and efficient forms of organizing the industrial production process. It would be in the interest of existing workers to attract foreign investors to manage their firms. The participation model could be a way to achieve this end without having to sacrifice the newly acquired private wealth. Perhaps history will show that the participation model will turn out to be a complement to, rather than a substitute for, existing privatization methods.

It is essential for the upswing in CEE countries to become faster and stronger. FDI is an important tool for achieving this goal because it brings in both money and expertise to the transition economies. To date, FDI has been disappointingly low, perhaps because too often it involved cash purchases of existing assets. We hope that the participation contract will be a better vehicle for direct investment and for boosting the economies of the CEE countries. 


\section{Appendix A. Family Silver and Xenophobia - Some Anecdotal Evidence}

\begin{tabular}{|c|c|c|}
\hline Date & Description of Evidence & Source \\
\hline \multicolumn{3}{|c|}{ Bulgaria } \\
\hline 9/95 & $\begin{array}{l}\text { Bill Coletti, executive director of the American Chamber of Commerce in Bulgaria: } \\
\text { 'there's not a long line of 'Fortune 500' companies contemplating investment in } \\
\text { Bulgaria, because they put every possible obstacle in the way'. }\end{array}$ & CEER, 9/95, \\
\hline 1995 & $\begin{array}{l}\text { Because of bureaucratic hurdles, Britain's Rover Group needs four years to complete a } \$ \\
6 \text { million acquisition of a state owned factory. }\end{array}$ & CEER, 9/95, \\
\hline \multicolumn{3}{|c|}{ Czech Republic } \\
\hline $\begin{array}{l}1992- \\
94\end{array}$ & $\begin{array}{l}\text { Czech government's 'family silver' policy requires that strong and viable enterprises be } \\
\text { kept in domestic ownership. }\end{array}$ & $\begin{array}{l}\text { Privatisation } \\
\text { Newsletter, } \\
28,11 / 94\end{array}$ \\
\hline $1 / 94$ & $\begin{array}{l}\text { Prime minister Vazlav Klaus: the Czech Republic has too much foreign investment; he } \\
\text { would prefer foreigners to hold back until privatization is finished. Central European } \\
\text { Economic Review reports growing public scepticism about foreign investment. }\end{array}$ & $\begin{array}{l}\text { CEER, } \\
\text { Summer } \\
1994\end{array}$ \\
\hline $5 / 94$ & $\begin{array}{l}\text { Miroslav Nevosad, general director of the state owned refinery Kaucuk, argues foreign } \\
\text { investors are more loyal to their home offices than to the Czech Republic. He names the } \\
\text { plan to restructure Czech refineries without foreign help the 'Czech Way'. }\end{array}$ & $\begin{array}{l}\text { WSJE, } \\
9 / 5 / 94\end{array}$ \\
\hline $10 / 94$ & $\begin{array}{l}\text { VW plan to scale down employment at Skoda and cut future investment raises Czech } \\
\text { anger. Minister of industry and trade, Vladimir Dlouhy, argues that Volkswagen has } \\
\text { violated the spirit of the contract. }\end{array}$ & $\begin{array}{l}\text { FT, } \\
24 / 10 / 94\end{array}$ \\
\hline 1994 & $\begin{array}{l}\text { Czech airline CSA withdraws from the strategic alliance with Air France, Czech } \\
\text { government paid } \$ 27 \mathrm{~m} \text { to buy out French stake. CSA now seeking a domestic investor. }\end{array}$ & $\begin{array}{l}\text { FT, } \\
24 / 11 / 94\end{array}$ \\
\hline $12 / 94$ & $\begin{array}{l}\text { Foreign banks and contractors interrupt common project }(\$ 200 \mathrm{~m}) \text { to develop Prague } \\
\text { airport because of disputes with the government over financial conditions. The } \\
\text { foreigners are replaced by locals. }\end{array}$ & $\begin{array}{l}\text { Economist, } \\
\text { F25/3/95 }\end{array}$ \\
\hline $1 / 95$ & The government tries to attract US investment to balance strong German investment. & $\begin{array}{l}\text { FT, } \\
9 / 1 / 95\end{array}$ \\
\hline 1995 & $\begin{array}{l}\text { Negotiating the privatisation of Czech refineries, the government demands that the } \\
\text { possible investor (IOC) promises not to increase its stake to over } 50 \% \text {. }\end{array}$ & $\begin{array}{l}\text { Economist, } \\
25 / 3 / 95\end{array}$ \\
\hline
\end{tabular}

Estonia

1994 Estonian public starts to demand more shares in privatization after realising that $40 \%$ of $\mathrm{BCE}$, assets have been sold to foreigners (Treuhand policy).

$6 / 94$

Hungary

1992 With $80 \%$ of privatization revenues coming from abroad, nationalist politicians, media $\quad$ BCE, and local businessmen claim disposal state owned companies at 'fire-sale prices'. $\quad 11 / 1 / 93$

1993 In 1993, many foreign bids were turned down in favour of lower bids from domestic $\quad$ BCE, management. Privatization revenue coming from abroad was reduced to 50\%. $\quad 4 / 94$

1994 Wall Street Journal Europe reports 'growing public disenchantment' with the foreigner- WSJE, 19 dominated privatization process.

10/94 After a lengthy tendering process with three foreign bidders interested in April 1994. 'HungarHotels', and after agreeing to sell the hotel to a US investor, the Hungarian $\quad 16 / 10 / 94$ \& government withdraws from the negotiations arguing that bids were too low. $\quad 16 / 1 / 95$

\section{Poland}

1991- Government declares tobacco a 'strategic sector', rejects bids by foreign investors. 
2/92 Privatization minister Tomasz Gruszecki says that former governments gave too much preference to foreigners; new projects would have to benefit Polish citizens.

Hunya

(1992)

1994 Polish trade union Solidarity views efforts to restructure FIAT Auto Poland's workforce

BCE, 2/94

as trying to introduce a 'slave system'.

1994 Privatization of some 'strategic' state industries like refining, telecommunications, and electric power has been held up because of fear of foreign dominance.

CEER,

Summer 94

BCE,

$10 / 94$ privatization is selling the country out to less-than-professional foreigners

SZ,

25/11/95

FT,

$10 / 11 / 95$

9/94 Prime minister Pawlak defers sale of 105 firms; questions needed to be answered as to

BCE, why so many companies were situated near the German border.

$10 / 94$

1991- During the last five years restructuring of the petroleum sector is said to been upheld by

1995 'sometimes-xenophobic political squabbles'.

CEER,

9/95.

1995 Prime minister Pawlak declares after his resignation that he had done his utmost to

HDB, 2

prevent foreign investors taking over Polish companies.

$10 / 96$

Russia

1994 Western firms are still restricted in share purchases: 51\% to workers, 29\% public offer.

1994 Investors complain of aggressive mood against foreigners. Articles in local press claim foreigners 'robbing Russia, exploiting workers, sending the money out of the country.'

1994 Deep-seated xenophobia is said to express itself in a host of contradictory regulations doing 'anything but welcoming investors'.

BCE, 4/94

BCE, 4/94

CEER,

Summer 94

1/95 Wladimir Polewnow, head of State Property Agency, claims second wave of privatization FAZ, should be accompanied by nationalization; national security must be guaranteed. 20/1/95.

5/95 Oxford Analytica reports proposals to create a Russian reinsurance company seem meant Oxford to recapitalize the sector without increasing the foreign companies' access to the market. Analytica

Daily Brief, $10 / 5 / 95$

\section{Slovak Republic}

1994 Marian Huska, vice president of the Movement for a Democratic Slovakia (HZDS), Economist, promises that, if returned to government, HZDS will 'correct' privatization. HZDS is 13/8/94 'pro foreign investment [but] in terms of development rather than purchase'.

6/95 HZDS-led government stops second wave of voucher privatization and excludes many

SZ, $14 / 7 / 95$ enterprises from privatization because of their 'national importance'.

\section{Slovenia}

1994 'Many people are afraid that rich Germans will come here and buy everything,' says Mira Puc, managing director of the Agency for Privatization. 'And it's true - if they CEER, have enough money they can buy what they want and we don't have the power to stop Autumn 94 them.'

Abbreviations: BCE: Business Central Europe; CEER: Central Eastern Economic Review; FAZ: Frankfurter Allgemeine Zeitung; FT: Financial Times; HDB: Hilfe Daily Briefing; SZ: Süddeutsche Zeitung; WSJE: Wall Street Journal Europe. 


\section{Appendix B. Earning a Risk Premium}

Let $K$ be the investor's wealth if uncommitted, $I$ its given restructuring investment and $q$ the fraction of dividends it claims. Thus, it offers a valuation $X=I \cdot q /(1-q)$ for the existing assets. Let $P$ be a cash price the investor pays to the privatization agency and suppose the investment generates a present value of random dividends $\pi$ whose expectation is $\mu(\pi)$ and standard deviation is $\sigma(\pi)$. The investor's wealth distribution $Y$ after deciding on the project has mean $\mu(Y)=K-I-P+q \mu(\pi)$ and standard deviation $\sigma(Y)=q \sigma(\pi)$. Together these define $(\mu, \sigma)$ combinations satisfying the participation line.

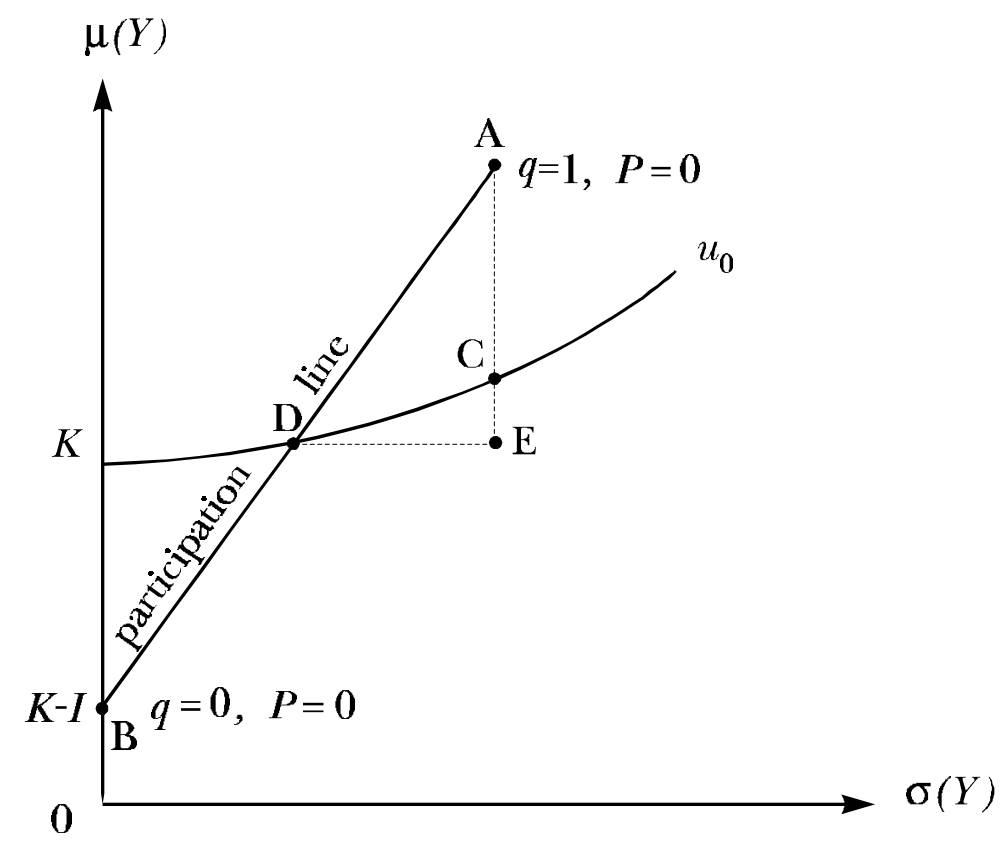

Figure A1. Privatization revenues and risk averse investors

If $q=1$ and $P=0$, the investor gets all returns, the government gets nothing. The investor's wealth distribution is given by point A. If $q=0$ and $P=0$, the government receives all returns and the investor nothing, although it pays for the restructuring investment. The investor's wealth distribution now is given by point B. Intermediate participatory solutions with $0<q<1$ are points on the participation line. If the investor receives all returns but pays a cash price $P$, its wealth distribution will be given by a point vertically below $\mathrm{A}$, where the distance between this point and point $\mathrm{A}$ gives the 
magnitude of the price. The cash price reduces the expected wealth but leaves the risk unaffected.

Suppose identical bidders compete for a privatization project. Competition will induce them to make bids that reduce their utility to the level they would attain without participating. In Figure A.1 this means that a point on the indifference curve $u_{o}-$ the curve originating at a wealth level $K$ on the ordinate - will be reached. Under the participation contract, the winning bid will be given by a level of $q$ that brings the investor to point $\mathrm{D}$ on the participation line. The government's expected present value of dividends equals the distance between points $\mathrm{A}$ and $\mathrm{E}$.

In a cash auction, the winning bid would instead be given by point $\mathrm{C}$. The government's revenue would only be AC. Obviously the government can, in addition, earn (or avoid paying) the risk premium CE if the participation model is used. The risk premium is positive if the investors are risk averse, because then the indifference curve $u_{o}$ is upward sloping. ${ }^{23}$

23 In this consideration the restructuring investment $I$ has been taken as given. It can be shown that the participation model will also generate a higher investment volume if this volume is part of the investor's choice and the government picks the investor who it expects will generate the higher present value of dividends in the future. See Demougin and Sinn (1994). 


\section{Appendix C. Joining the Winner}

This appendix shows that a participation contract extracts more of the winning bidder's rent. Abstract from risk aversion and consider a class of investors who differ in knowhow and in the present value of total dividends, $\pi$, which they can generate given the necessary investment $I$. Each investor knows its own $\pi$; neither the government nor other investors know this. Let $\pi_{1}$ and $\pi_{2}, \pi_{1}>\pi_{2}>I$, be the present value of dividends generated by the best and second best investor, respectively.

Consider a cash auction. Let $P_{1}$ and $P_{2}$ be the maximum cash prices the two investors are willing to pay for the existing assets. Clearly

$$
P_{i}=\pi_{i}-I, i=1,2 \text {; }
$$

The maximum willingness to pay equals the present value of the cash flow the restructuring investment can generate. Investor 1 wins the bid and pays an expected price equal to (or marginally above) investor 2's willingness to pay. Thus investor 1 will enjoy an auction rent, $R_{1}$ given by

$$
R_{1}^{\text {Cash }}=P_{1}-P_{2}=\pi_{1}-\pi_{2}
$$

and the government will collect a privatisation revenue, $G$, equal to

$$
G^{\text {Cash }}=P_{2}=\pi_{2}-I \text {. }
$$

Next consider an auction under the participation contract. Let $X_{1}$ and $X_{2}$ be the maximum valuations for the existing state assets which investors 1 and 2 are willing to offer and let $q_{1}$ and $q_{2}$ be the respective minimum relative participation rates claimed by these investors. By the definition of the participation rate,

$$
q_{i} \equiv \frac{I}{I+X_{i}}, i=1,2 .
$$

Bids are in terms of $X_{i}$ or equivalently in terms of $q_{i}$. Analogously to (C1)

$$
X_{i}=\pi_{i}-I, i=1,2 .
$$

Equations (C4) and (C5) imply that

$$
q_{i}=\frac{I}{\pi_{i}}, i=1,2 .
$$


Asking for bids in terms of $q$ of $X$ implies that investor 1 wins but has to bid only marginally higher than investor 2's valuation. The winner's auction rent is therefore $R_{1}^{\text {Part. }}=\left(q_{2}-q_{1}\right) \pi_{1}$ which, after a few rearrangements using (C6), can be written as

$$
R_{1}^{\text {Part. }}=\left(\pi_{1}-\pi_{2}\right) \frac{I}{\pi_{2}} .
$$

A comparison with $(\mathrm{C} 2)$ reveals that $R_{1}^{\text {Part. }}<R_{1}^{\text {Cash }}$ if, as assumed, $\pi_{2}>I$; i.e., if it is strictly profitable to restructure the firm. Obviously, the participation contract enables the government to reduce the winner's auction rent.

The present value of dividends the government is able to collect with the participation contract should therefore be higher than the potential cash revenue. The present value of the government's dividends equals the share the second best bidder is willing to cede to the government times the best bidder's dividend value:

$$
G^{\text {Part. }}=\left(1-q_{2}\right) \pi_{1}
$$

To interpret this expression, use (C6) to write (C3) in the form

$$
G^{\text {Cash }}=\left(1-q_{2}\right) \pi_{2}
$$

and combine (C8) and (C9):

$$
G^{\text {Part. }}=G^{\text {Cash }} \frac{\pi_{1}}{\pi_{2}}
$$

Equations (C8) and (C9) show that the participation contract dominates the cash sales contract. Equation (C10) shows that the magnitude of the gain will depend on the ratio of the present values of dividends as expected by the best and the second best bidders.

Note that, in principle, this result can still be attained if investors can shift a considerable part $\mathrm{g}<1$ of the eastern firm's profits by using transfer pricing tricks. The maximum bid is implicitly given by

$$
I=q_{i}(1-\gamma) \pi_{i}+\gamma \pi_{i} \Rightarrow q_{i}=\frac{I-\gamma \pi_{i}}{\pi_{i}(1-\gamma)} .
$$

The larger $\mathrm{g}$, the larger the future profit shifting possibilities. (C11) indicates that this will also increase the investors' maximium bids. The government's discounted revenue now is $\left(1-q_{2}\right)(1-\gamma) \pi_{1}$. Combining (C6), (C9) and (C11) shows that this revenue is the same as in (C10). 


\section{BIBLIOGRAPHY}

Bolton, P. and G. Roland (1992): "Privatisation in Central and Eastern Europe," Economic Policy, 12, pp. 275-309.

Bond, E.W. and L.W. Samuelson (1989): "Strategic behaviour and the rules for international taxation of capital,” Economic Journal 99, pp. 1099-1111.

Boycko, M., A. Shleifer, and R.W. Vishny (1994): "Voucher privatisation," Journal of Financial Economics 35, pp. 249-266.

Crémer, J. (1987): “Auctions with contingent payments: Comment,” American Economic Review 77, p. 746.

Demougin, D. and H.-W. Sinn (1994): "Privatisation, risk taking and the communist firm," Journal of Public Economics 55, pp. 203-231.

Eaton, J. and M. Gersovitz (1984): "A theory of expropriation and deviations from perfect capital mobility," Economic Journal 94, pp. 16-40.

EBRD (1994): Transition report, EBRD, London.

- (1995): Transition report, EBRD, London.

Goleva, P. (1993): "Neuere Tendenzen in der Joint-Ventures-Rechtsregelung Osteuropäischer Staaten," WGO Monatshefte für Osteuropäisches Recht 35, pp. 219-230.

Hansen, R. G. (1985): “Auctions with contingent payments," American Economic Review 75, pp. 862-865.

Healey, P. M. and K. G. Palepu (1993): "International corporate equity acquisitions: Who, where, and why?," in: K. A. Froot (ed.), Foreign direct investment, University of Chicago Press, Chicago and London, pp. 231-253.

Kant, C. (1995): "Minority ownership, deferral, perverse intrafirm trade and tariffs," International Economic Journal 9, pp. 19-37.

Keen, M. (1991): "Corporation tax, foreign investment and the single market," in: L.A. Winters and A. Venables (eds.), European integration: Trade and industry, Cambridge University Press, Cambridge, pp. 165-199.

Konrad, K. (1996): "Foreign direct investment, transfer pricing and ownership structure," mimeo, Free University, Berlin.

Korn, R. and H. Debatin (1982): Doppelbesteuerung. Sammlung der zwischen der $B R$ Deutschland und dem Ausland bestehenden Abkommen über die Vermeidung der Doppelbesteuerung, Kommentar (loose-leaf, 4 Vols.), Beck, Munich.

Lane, S.J. (1994): "The pattern of foreign direct investment and joint ventures in Hungary," Communist Economies and Economic Transformation 6, pp. 341-365.

Lipsey, R. E. (1993): "Foreign direct investment in the United States: Changes over three decades," in: K. A. Froot (ed.), Foreign direct investment, University of Chicago Press, Chicago and London, pp. 113-172.

Luo, Y. (1996): "Evaluating the performance of strategic alliances in China," Long Range Planning 29, pp. 534-542. 
Maskin, E. S. (1992): “Auctions and privatisation,” in: H. Siebert (ed.), Privatisation. Symposium in honor of Herbert Giersch, Mohr, Tübingen, pp. 115142.

Meade Committee (1978): The structure and reform of direct taxation. Report of a committee chaired by J.E. Meade, Allen \& Unwin, London.

McAfee, R. P. and J. McMillan (1986): "Bidding for contracts: A principal-agent analysis," Rand Journal of Economics 17, pp. 326-338.

- (1987): "Auctions and Bidding," Journal of Economic Literature 25, pp. 699738.

OECD (1991): Taxing profits in a global economy: Domestic and international issues, OECD, Paris.

- (1994): Assessing investment opportunities in economics in transition, OECD, Paris.

- (1995): Taxation and foreign direct investment: The experience of the economies in transition, OECD, Paris.

Riley, J. G. (1988): "Ex post information in auctions," Review of Economic Studies 40, pp. 409-430.

Rollo, J. and A. Smith (1993): "The political economy of Eastern Europe with the European Community: Why so sensitive?," Economic Policy 16, 16, pp. 139-181.

Samuelson, W. (1987): "Auctions with contingent payments: Comment," American Economic Review 77, pp. 740-745.

Sinn, G. and H.-W. Sinn (1991): Kaltstart. Volkswirtschaftliche Aspekte der deutschen Vereinigung, Mohr, Tübingen. (English edition: Jumpstart. The economic unification of Germany, MIT Press, Cambridge (MA), 1992.)

Sinn, G. and H.-W. Sinn (1993): "Participation, capitalization and privatisation. Report on Bolivia's current political privatisation debate," CES working paper 49.

Sinn, H.-W. (1995): "Staggering along: Wages policy and investment support in East Germany," Economics of Transition 3, pp. 403-426.

Thoburn, J., H. M. Leung, E. Chau and S. H. Tang (1990): Foreign investment in China under the open policy, Avebury, Aldershot.

UN/ECE (1994): Statistical survey of recent trends in foreign investment in East European countries, 30 November 1994, Trade/R.624.

- (1995): Statistical survey of recent trends in foreign investment in East European countries, 23 November 1995, Trade/R.636.

UNCTAD (1995a): Recent developments in international investment and transnational corporations, 21 February 1995, TD/BITNC/2.

- (1995b): Foreign direct investment in Central and Eastern Europe, 19 April 1995, TD/B/ITNC/Misc.2.

Weichenrieder, A. J. (1996): "Transfer pricing, double taxation, and the cost of capital," Scandinavian Journal of Economics 98, p. 445-452.

— (1995): Direktinvestition und Besteuerung, Mohr, Tübingen. 
Welfens, P. J. J. (1994): "Foreign direct investment and privatisation," in: A. Schipke and A.M. Taylor (eds.), The economics of transformation: Theory and practice in the new market economies, Springer, Berlin, pp. 129-169.

Wolfstetter, E. (1996): “Auctions: An introduction," mimeo, Humboldt University, Berlin (forthcoming in: Journal of Economic Surveys).

Zhang, L. -Y and J. Thoburn (1995): "The evolution of Chinese foreign investment policy," in: P. Cook and F. Nixson (eds.), The move to the market? Trade and industy policy reform in transitional economies, MacMillan, Houndmills, pp. 139-157. 